\title{
Molecular Identification of Genes Involved in Magnetosome Synthesis in Magnetospirillum magneticum AMB-1
}

\author{
Identifikasi Molekuler Gen yang Terlibat dalam Sintesis Magnetosom pada \\ Magnetospirillum magneticum AMB-1
}

\author{
Aris Tri Wahyudi
}

Department of Biology, Faculty of Mathematics and Science, Bogor Agricultural University Jl. Agatis Kampus IPB Darmaga-Bogor 16680 E-mail: aristri2003@yahoo.com

\begin{abstract}
Abstrak
Satu mutan Magnetospirillum magneticum AMB-1 yang tidak bersifat magnetik, yang didesain NMA41, dikonstruksi melalui mutagenesis dengan transposon Mini-Tn5Km1 untuk mengidentifikasi gen yang terlibat dalam sintesis magnetosom. Mutagenesis dengan transposon dilakukan melalui konjugasi antara M. magneticum AMB-1 dan Escherichia coli $\mathbf{S 1 7 - 1}(\lambda$ pir) yang membawa plasmid pUTmimi-Tn5Km1. Frekuensi transkonjugasi tertinggi berkisar $1.8 \times 1^{-7}$ sel per resipien. NMA41 tidak respon terhadap bidang magnet dan kehilangan kemampuan dalam mensintesis magnetosom. Sekuens DNA/gen yang disisipi oleh transposon (dinamakan DNA pengapit) diisolasi dengan PCR yang dibalik (inverse PCR) dan diklon ke dalam plasmid pCR2.1. Penyejajaran sekuen DNA dari DNA pengapit terhadap sekuens DNA genom lengkap AMB-1 dapat mengidentifikasi sebuah kerangka baca terbuka (open reading frame, ORF2) dalam suatu operon yang terdiri dari 4 gen. Sekuen asam amino yang dideduksi dari ORF2 menunjukkan homologinya dengan protein domain GGDEF dari Magnetospirillum magnetotacticum MS-1 (identik 90\%; kemiripan 95\%) yang mempunyai fungsi dalam mekanisme transduksi sinyal. Gen atau operon ini diduga berfungsi selama proses sintesis magnetosom pada $M$. magneticum AMB-1.
\end{abstract}

Kata kunci: Magnetospirillum magneticum AMB-1, Magnetosom, Inverse PCR, Mutagenesis dengan Transposon, Transduksi Sinyal

Diterima: 02 Februari 2009, disetujui: 07 Mei 2009

\section{Introduction}

Magnetotactic bacteria synthesize intracellular particles of magnetite $\left(\mathrm{Fe}_{3} \mathrm{O}_{4}\right)$ which are aligned in chains and enveloped by a membrane (Matsunaga et al., 1991). These magnetic chain structures, known as magnetosomes, confer a magnetic dipole and magnetotaxis to the cells allowing bacterial orientation along geomagnetic field lines. In natural habitats, large populations of magnetotactic bacteria are usually located at the sediment-water interface in freshwater environments where the oxygen is limited (microaerobic condition). As the same as the other magnetotactic bacteria synthesizing magnetosome, $M$. magneticum AMB-1 is classified as proteobacteria subdivision $\alpha$ (Burgess et al., 1993). Previous study has investigated the ability of $M$. magneticum AMB-1 to grow in agar medium and it would facilitated any genetic analysis such as conjugation or transformation, in order to study the behavior, biochemical and physiological aspects of this bacterium. Therefore, $M$. magneticum AMB-1 has been known to be the most intensively studied among other typical magnetotactic bacteria (Matsunaga et al., 1992; Wahyudi et al., 2001; Wahyudi et al., 2003). 
To elucidate further the biosynthesis of magnetosome in magnetotactic bacteria, a molecular genetic approach has been conducted especially for those magnetosom's membrane associated-protein, such as Mam22 of $M$. magnetotacticum MS-1 (Okuda and Fukumori 2001), MpsA (Matsunaga et al., 2000), and Mms16 (Okamura et al., 2001) from M. magneticum AMB-1. Several genes are also proposed to be involved in magnetosome formation (Arakaki et al., 2003; Wahyudi et al., 2003). Hence, the molecular mechanisms by which magnetosome is formed remain unclear, primarily in signal transduction aspects due to the complex involvement of several genes (Wahyudi, 2004).

Nowadays, genetic manipulation of genes in bacteria is easy to conduct, caused by the utilizing of transposon which carried out an antibiotic resistance-gene. The insertion of transposon in to the gene will cause a gene inactivation and a mutation which yield physically or genetically marker at the inserting site (Reznikoff, 2002). Transposon mini-Tn5 is one of the most broadly use transposon particularly for molecular genetic analysis in Gram negative bacteria (Herero et al., 1990). Mini-Tn5 is a derivative transposon of Tn5 is flanked by $19 \mathrm{bp}$ of inverted repeat sequences (inner and outer), and a transposase gene is located outside of the transposon mini-Tn5. Therefore, mini-Tn5 will remain stable in bacterial genome after the insertion (DeLorenzo et al., 1990).

This study describes the analysis of upstream and downstream of the genomic DNA sequence of $M$. magneticum AMB-1 which is interrupted by transposon mini-Tn5. We have isolated, cloned, and sequenced gene involved in magnetosome synthesis in M. magneticum AMB-1.

\section{Materials and Methods}

\section{Transposon mutagenesis in M. magneticum AMB-1}

Diparental mating as described by Wahyudi et al., (2001) was used in order to localize the gene that might be involved in magnetosome synthesis. Transposon mini-
Tn5Km1 carried by a plasmid pUT (designated as pUTmini-Tn5Km1) (DeLorenzo et al., 1990) was brought in Escherichia coli S17-1 ( $\lambda$ pir) and pointed out as a donor strain. Transposon delivery was carried out through conjugation between $M$. magneticum AMB-1 (recipient) and donor cell at 1:1, 1:10 and 10:1 ratio of $10^{9}$ cells.

\section{Analysis of a non-magnetic mutant (NMA)}

A single mutant obtained from transposon mutagenesis (designed NMA41) was further analyzed for its molecular genetic aspects, particularly a gene that may be responsible in magnetosome biosynthesis. Isolation of DNA genome was done by the CTAB method as described by Wilson (1995), the DNA genome was subsequently digested with EcoRI and further southern hybridization using resistance kanamycin gene $(\mathrm{Km} 1)$ from mini-Tn5Km1 as a probe (Wahyudi et al., 2001). The hybridization was performed in proper procedure according to the manufacturer's instructions (Boehringer, Mainhaem, Germany). Whereas the isolation of DNA flanking transposon was conducted by inverse polymerase chain reaction (inverse PCR) technique, as described by Wahyudi (2007).

\section{Cloning and sequence analysis}

The inverse PCR product of the DNA (1.6 kb, see below) obtained by inverse PCR was electrophoresed in $1 \%$ agarose gel electrophoresis and further purified with Gene Clean Kit (Bio 101). Moreover, the DNA fragment was cloned into a plasmid pCR 2.1 $(3.9 \mathrm{~kb})$ according to the manufacturer's instructions (Invitrogen, USA), and it resulted a recombinant plasmid, designed as pCR2.1-41

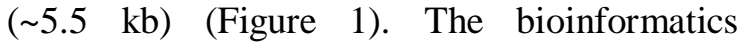
information was acquired from the nucleotide sequence of the amplicon DNA. The DNA sequencing was carried out by DNA Sequencer ABI 377 (Perkin Elmer, USA). Afterwards, the nucleotide sequence of amplicon DNA was aligned against the complete genome sequence of M. magneticum AMB-1 (Matsunaga et al., 2005) to identify a gene interrupted by transposon that was involved in magnetosome synthesis in M. magneticum AMB-1. 


\section{Results and Discussion}

The highest frequency of conjugation was about $1.8 \times 10^{-7}$ cell per recipient resulted from the conjugation ratio of 10:1 of AMB-1 cell (recipient) and donor cell (E. coli S-17 $\lambda$ pir) (Table 1). With the same usage of transposon, this frequency remain higher than $B$. japonicum which have frequency of conjugation was about $1.7 \times 10^{-9}$ cell per recipients (Wahyudi et al., 1998) or Gluconobacter oxydans which have frequency of conjugation was about $1.0 \times 10^{-8}$ cells per recipient (Gupta et al., 1997).

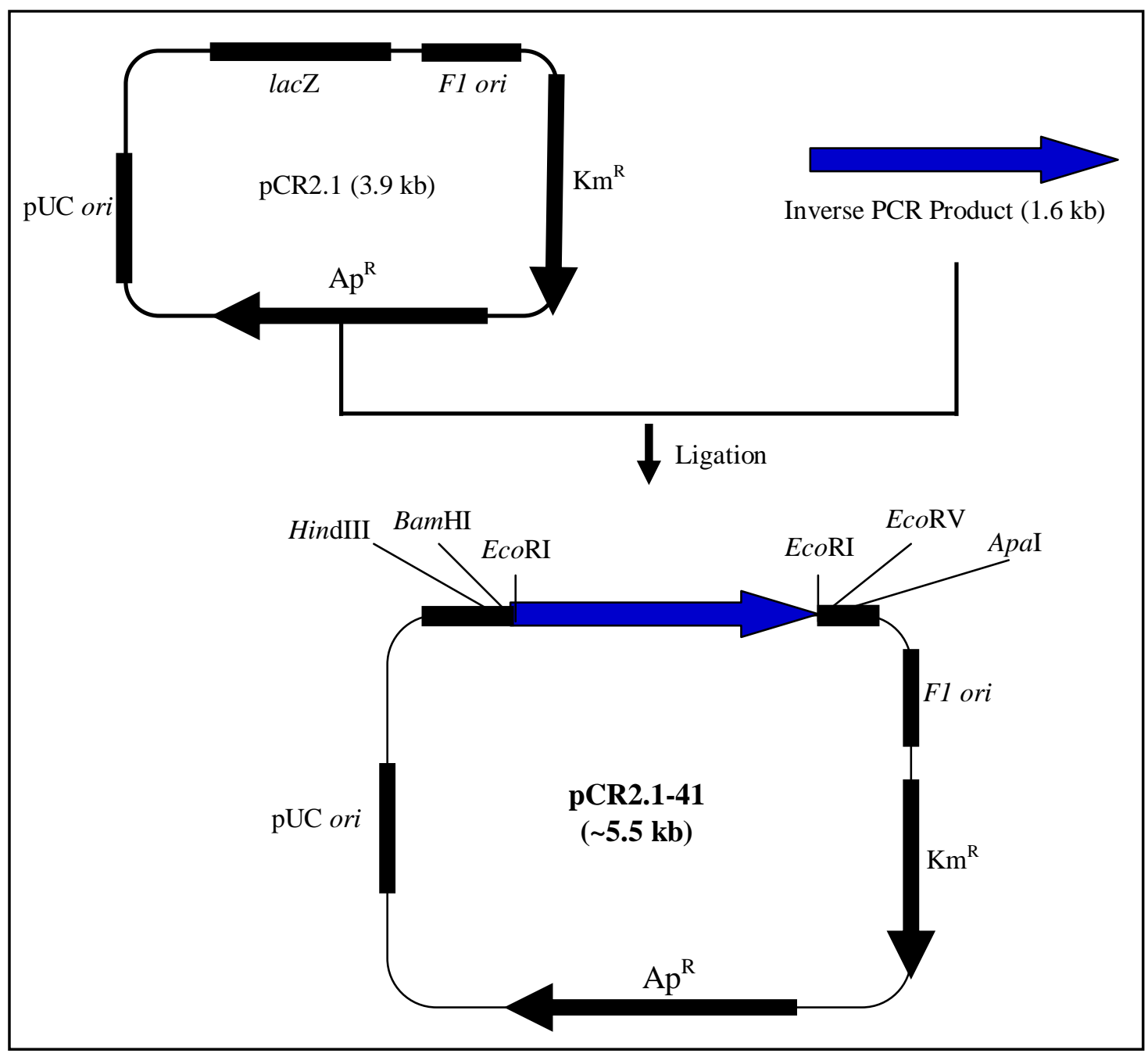

Figure 1. Construction of a recombinant plasmid pCR2.1-41 ( 5.5 kb).

Table 1. Frequency of transconjugation of transposon mini-Tn5Km1from E. coli to Magnetospirillum magneticum AMB-1.

\begin{tabular}{cc}
\hline \hline Conjugation between $\boldsymbol{E}$. coli and AMB-1 & Frequency $^{\text {a) }}$ \\
\hline \hline $10: 1$ & $0.7 \times 10^{-8}$ \\
$1: 1$ & $2.8 \times 10^{-8}$ \\
$1: 10$ & $1.8 \times 10^{-7}$ \\
\hline
\end{tabular}

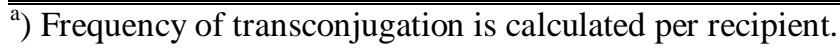


The screening of transconjugants was conducted in magnetospirillum growth medium (MSGM) (Blakemore et al., 1979) supplemented with kanamycin $\left(5 \mu \mathrm{g} \mathrm{ml}^{-1}\right)$. It was obtained only one white colony (designated as NMA41) that was able to grow on the medium and lacked of magnetosome inside of the cell after observing through light microscope (Olympus BH2, Tokyo, Japan) or transmission electron microscopy (TEM) (data not shown). Meanwhile, the transconjugant colony that was still able to synthesize magnetosome will appear in black color in the same medium.

The hybridization assay of NMA41 genome (digested with EcoRI) with $\mathrm{Km} 1$ probe has revealed a single hybridization band at $2 \mathrm{~kb}$ (Figure 2). This result convinced the NMA41 as a mutant product of the transposon mutagenesis. The inverse PCR of NMA41 genome which was restricted with EcoRV yielded a single band at $1.6 \mathrm{~kb}$ (amplicon DNA) (Figure 2). This amplified DNA indicated the sequence of DNA genome inserted by transposon (genomic DNA flanking the transposon). Furthermore, these flanking DNA sequence are a good genetic tool to identify and determine genes involved in magnetosome synthesis from the complete genome sequence of $M$. magneticum AMB-1 (Matsunaga et al., 2005).

The alignment of DNA sequence flanking transposon (gene interrupted by transposon) revealed that an open reading frame (ORF2) as a complete gene was determined denoted by the start codon (ATG) and ended with stop codon (TGA). The homology searches analysis result was obtained by using the Basic Local Alignment Search Tool (BLAST) program of the databases (Altschul et al., 1998). The bioinformatics analysis showed a high homology of ORF2 to the gene which responsible to produce adenylate cyclase/phosphodiesterase protein (GGDEF). This protein functioned as a signal transduction in Magnetospirillum magnetotacticum MS-1. The percentage of identity and similarity of ORF2 to the GGDEF protein were $90 \%$ and $95 \%$, respectively (Table 2 ). Highly homology percentage of those AMB-1 and MS-1 are agreeable according to the fact that those two bacterial strains are magnetotactic bacteria but only distinctive in strain taxa. AMB-1 was previously described as magnetotactic a bacterium that was able to grow in solid agar medium and also in aerobic conditions, whereas MS-1 could not be cultivated in those kind of conditions (Blakemore et al., 1979).

Generally bacteria have distinctive 12-22 of GGDEF domain-proteins (Pei and Grishin, 2001). Matsunaga et al., (2005) have reported that M. magneticum AMB-1 possessed 46 genes which expressed protein with GGDEF domain as regulatory protein in signal transduction process. The adenylate cyclase/ phosphodiesterase (GGDEF) is responsible as a response regulator and mostly found as couple with sensor protein that is involved in regulation of gene expression. In this case, the sensor protein was located downstream of ORF2 sequence, called ORF3 sequence, that had homology with CheY-like receiver protein (Table 2). The analysis of downstream and upstream domain of ORF2 has revealed a cluster of genes consists of four genes organized in an operon. The expression of these genes were regulated by the same promotor, which was identified and located upstream domain of ORF1, meanwhile, the terminal transcription domain was identified downstream of ORF4 sequence (data not shown). Therefore, we suggested that the ORF2 together with ORF1, ORF3 and ORF4 formed an operon and assumed to be involved in biosynthesis of magnetosome in $M$. magneticum AMB-1.

In this study, the insertion of transposon into ORF2 sequence (responsible to produce GGDEF protein) caused the lack of magnetosome synthesis in $M$. magneticum AMB-1. This gene is presumably express a regulatory protein which commonly found in couple with gene which encode a sensor protein, called two component system, such as Che-Y receiver domain (Table 2). Most bacteria have two components system in signal transduction which consist of regulatory and sensor protein. This system regulates the expression of some genes as response of environmental signals like nitrogen availability, phosphate availability, $\mathrm{pH}$, atractant, reduction- 
oxidation, or oxygen availability. The mechanisms of two components system in respond to the environmental signal has been elaborated. The recognition of any specific environmental signal by sensor protein will cause an autophosphorilation reaction of sensor protein, and then the phosphate is further used to activate the regulatory protein (McCleary and Stock, 1994). The activated regulatory protein will stimulate the expression of some particular genes. In this case, we assumed that the signal transduction will stimulate an expression of genes involved in biosynthesis of magnetosome that may be organized in operon. Therefore, the study of genes and the role of regulatory protein in biosynthesis of magnetosome is tremendously necessary to elucidate magnetosome synthesis in $M$. magneticum AMB-1.

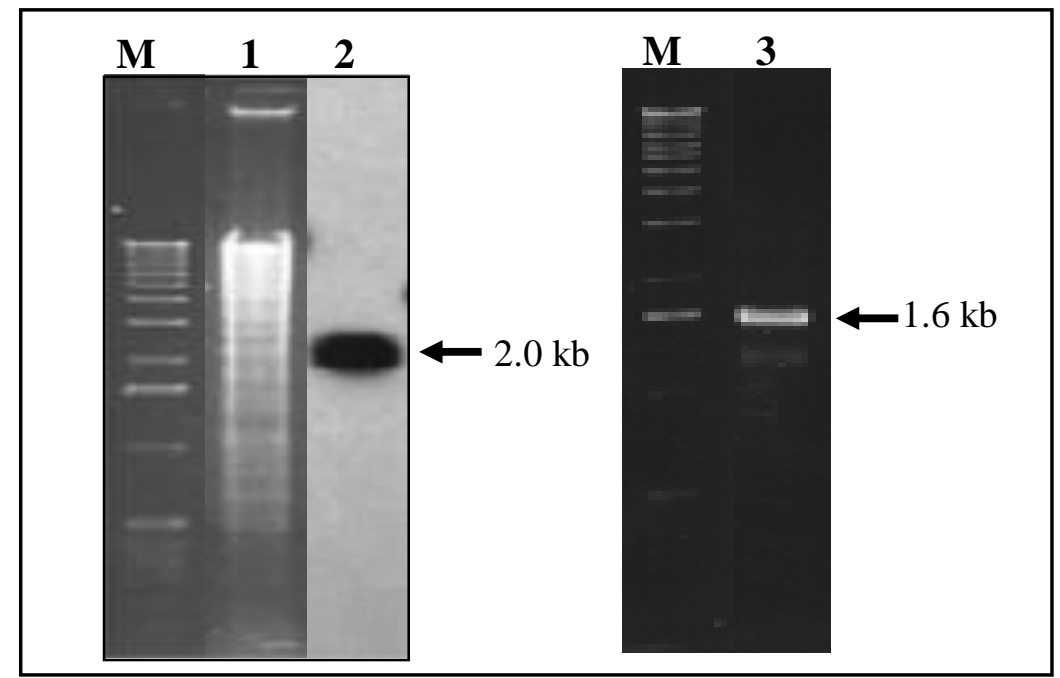

Figure 2. Agarose gel electrophoresis of M. magneticum AMB-1 NMA41 mutant genome digested With EcoRI (1) and $2.0 \mathrm{~kb}$ of Southern hybridization band of AMB-1 mutant genome using a $\mathrm{Km} 1$ gene as a probe (2), and DNA fragment flanking transposon amplified by inverse PCR $(1.6 \mathrm{~kb})$. M. $1 \mathrm{~kb}$ DNA ladder as a marker.

Table 2. Homology searches of open reading frames (ORF) of an operon involved in magnetosome synthesis in Magnetospirillum magneticum AMB-1.

\begin{tabular}{ccclccl}
\hline \hline ORF & $\begin{array}{c}\text { Size } \\
(\mathbf{b p})\end{array}$ & $\begin{array}{c}\text { Amino acid } \\
\text { Residue }\end{array}$ & Homologous Protein & Accesion No. & $\begin{array}{c}\text { Id/Sim } \\
(\boldsymbol{\%})\end{array}$ & Microorganism \\
\hline \hline 1 & 495 & 170 & $\begin{array}{l}\text { Uncharacterized low- } \\
\text { complexity protein }\end{array}$ & ZP_00054172 & $85 / 91$ & M. Magnetotacticum MS-1 \\
2 & 1059 & 398 & GGDEF domain & ZP_00054171 & $90 / 95$ & M. Magnetotacticum MS-1 \\
3 & 729 & 126 & CheY-like receiver & ZP_00054170 & $90 / 100$ & M. Magnetotacticum MS-1 \\
4 & 711 & 470 & Hypothetical protein & ZP_0054169 & $85 / 95$ & M. Magnetotacticum MS-1 \\
\hline \hline Id: Identity; Sim: Similarity & & & &
\end{tabular}




\section{Conclusion}

A gene for adenylate cyclase/ phosphodiesterase (GGDEF) involved in magnetosome synthesis has been identified through mini-Tn5 transposon mutagenesis. This gene is organized in an operon consisting of four genes. This gene or operon is predicted to be involved in magnetosome synthesis in Magnetospirillum magneticum AMB-1.

\section{Acknowledgements}

Part of this research was conducted at Department of Biotechnology, Tokyo University of Agriculture and Technology, Japan, especially in Matsunaga-Takeyama Laboratory. Therefore, the author thanks and appreciates to Prof. Tadashi Matsunaga for all the supports that have been given in order to conduct this research. I also thank to Rika Indri Astuti, M.Si, Department of Biologi FMIPAIPB, for technical assistance to prepare this paper.

\section{References}

Altschul, S.F., Gish, W., Miller, W., Myers, E.W. and Lipman, D.J. 1998. Basic local alignment search tool. J. Mol Biol 215: 403-410.

Arakaki, A., Webb, J. and Matsunaga, T. 2003. A novel protein tighly bound to bacterial magnetic particles in Magnetospirillum magneticum strain AMB-1. J. Biol Chem 278: 8745-8750.

Blakemore, R.P., Maratea, D. and Wolf, R.S. 1979. Isolation and pure culture of a fresh water magnetic spirillum in defined growth medium. J. Bacteriol 140: 720-729.

Burgess, J.G.., Kawaguchi, R., Thornhill, R.H. and Matsunaga, T. 1993. Evolutionary relationship among Magnetospirillum strains inferred from phylogenetic analysis of $16 \mathrm{~S}$ rDNA sequences. J. Bacteriol 175: 66896694.

DeLorenzo, V., Hererro, M., Jakubzik, U. and Timmis, K.N. 1990. Mini-Tn5 transposon derivatives for insertion mutagenesis, promoter probing, and chromosomal insertion of cloned DNA in gram-negative eubacteria. J. Bacteriol 172: 6568-6572.
Gupta, A., Verma, V. and Qazi, G.N. 1997. Transposon induced mutation in Gluconobacter oxydan with special reference to its direct-glucose oxydation metabolism. FEMS Microbiol Lett 147: 181-188.

Herrero, M., DeLorenzo, V. and Timmis, K.N. 1990. Transposon vector containing non antibiotic resistance selection markers for cloning and stable chromosomal insertion of foreign genes in gram negative bacteria. J. Bacteriol 172: 6557-6567.

McCleary, W.R. and Stock, J.B. 1994. Acetyl phosphate and the activation of two-component response regulators. J. Biol Chem 269: 31567-31572.

Matsunaga, T., Tsujimura, N., Okamura, Y. and Takeyama, H. 2000. Cloning and characterization of a gene, mpsA, encoding a protein associated with intracellular magnetic particles from Magnetospirillum sp. strain AMB-1. Biochem Biophys Res Commun 268: 932-937.

Matsunaga, T., Okamura, Y., Fukuda, Y., Wahyudi, A.T., Murase, Y. and Takeyama, H. 2005. Complete genome sequence of the facultative anaerobic magnetotactic bacterium Magnetospirillum sp. Strain AMB-1. DNA Res 12:157-166.

Matsunaga, T., Sakaguchi, T. and Todokoro, F. 1991. Magnetite formation by a magnetic bacterium capable of growing aerobically. Appl Microbiol Biotechnol 35: 651-655.

Matsunaga, T., Nakamura, C., Burgess, J.G. and Sode, K. 1992. Gene transfer in magnetic bacteria: transposon mutagenesis and cloning of genomic DNA fragments required for magnetosome synthesis. J. Bacteriol 174: 2748-2753.

Okamura, Y., Takeyama, H. and Matsunaga, T. 2001. A magnetosome-specific GTPase from the magnetic bacterium Magnetospirillum magneticum AMB-1. J. Biol Chem 276: 48183-48188.

Okuda, Y. and Fukumori, Y. 2001. Expression and characterization of a magnetosome-associated protein, TPR-containing MAM22, in Escherichia coli. FEBS Lett 491: 169-173.

Pei, J. and Grishin, N.V. 2001. GGDEF domain is homologous to adenylyl cyclase. Protein 42: 210-216.

Reznikoff, W.S. 2002. Transposition of transposon Tn5. In: Craig, N.L., Craig, R., Gellert, M. and Lambowitz (Eds.). Mobile DNA II. Washington DC: ASM Press. 
Wahyudi, A.T. 2004. Magnetosome formation in bacteria. Indones J. Microbiol 9: 39-42.

Wahyudi, A.T. 2007. Rapid and simple amplification of genomic DNA sequences flanking transposon. Microbiol Indones 1: 1-5.

Wahyudi, A.T., Suwanto, A., Imas, T. and Tjahjoleksono, A. 1998. Screening of acid-aluminium tolerant Bradyrhizobium japonicum strains: analysis of marker genes and competition in planta. Aspac J. Mol Biol Biotechnol 6: 1320.

Wahyudi, A.T., Takeyama, H. and Matsunaga, T. 2001. Isolation of Magnetospirillum magneticum AMB-1 mutants defective in bacterial magnetic particle synthesis by transposon mutagenesis. Appl Biochem Biotechnol 91: 147-154.
Wahyudi, A.T., Takeyama, H. and Matsunaga, T. 2003. Characterization of aldehyde ferrodoxin oxidoreductase gene defective mutant in Magnetospirillum magneticum AMB-1. Biochem Biophys Res Commun 303: 223-229.

Wilson, K. 1995. Preparation of genomic DNA from bacteria. In: Ausubel, F.M. et al., (Eds). Current Protocol in Molecular Biology. Vol. I. New York: John Wiley and Son. P. 2.4.12.4.5. 